\title{
TNF- $\alpha$ IN THE DEVELOPMENT OF INSULIN RESISTANCE AND OTHER DISORDERS IN METABOLIC SYNDROME
}

\author{
Simona Gwozdziewiczová, Radka Lichnovská, Rabha Ben Yahia, Rudolf Chlup, \\ Jiří Hřebíček ${ }^{\dagger}$
}

Institute of Physiology, Faculty of Medicine, Palacky University Olomouc, Hněvotínská 3, 77515 Olomouc, Czech Republic; E-mail:simgwozd@tunw.upol.cz

Received: May 10, 2005; Accepted: June 3, 2005

Key words: Insulin resistance/Obesity/Gender differences /TNF- $\alpha$

Insulin resistance and obesity are very frequent disorders and are described as the dominant risk factors for cardiovascular disease. The aim of this study was to analyze the interrelations between several metabolic variables (including TNF- $\alpha$ ) and factors related to insulin resistance in groups of both normal and hyperlipidemic postmenopausal women and men of appropriate age, and to attempt to elucidate the gender differences. The study was carried out on 70 out-patients of the Metabolic Center. From these, 40 patients (20 men and 20 women) were selected with mild hyperlipidemia. Two other groups (10 men and 20 women) with approximately normal serum lipids parameters were taken as "controls". In hyperlipidemic women the mean serum concentration of the TNF- $\alpha$ was no different from that in the control group in spite of the fact that values of HOMA IR, insulin, proinsulin and lipid parameters increased significantly. In hyperlipidemic men we have found the decrease in TNF- $\alpha$ in comparison with the control group. In all four groups the statistical analysis showed correlations between metabolic parameters (including TNF- $\alpha$ ) and parameters related to insulin resistance. Also differences in relation to the gender have been found. Multiple regression analysis demonstrated the important role of TNF- $\alpha$ in the regulation of both the insulin resistance and in the secretion of insulin in women. In men, BMI and HDL-cholesterol played a dominant role, while the role of TNF- $\alpha$ seemed to be minimal.

\section{INTRODUCTION}

The prevalence of the metabolic syndrome is constantly growing ${ }^{1}$. It may affect over half of the Czech population ${ }^{2}$. From the clinical point of view, the metabolic syndrome $\mathrm{X}$ and in particular insulin resistance play a key role in the development of cardiovascular disease. The level of insulin resistance is associated with increased occurrence of myocardial infarction, stroke and peripheral vascular disease ${ }^{3}$.

One factor that plays a role in the development of insulin resistance is the tumor necrosis factor alpha $(\mathrm{TNF}-\alpha)$. TNF- $\alpha$ is a pleiotropic cytokine which occurs in many pathological processes (including inflammation, allergy, congestive heart failure etc.) It has been discovered that TNF- $\alpha$ inhibits insulin signal transduction, has influence on lipid metabolism and modulates many other factors involved in the pathogenesis of insulin resistance (e.g. PPAR $\gamma$, adiponectin, resistin). The role of TNF- $\alpha$ in the development of insulin resistance associated with obesity has been the subject of many current research projects. Recent studies have confirmed an important role of TNF- $\alpha$ in the pathogenesis of insulin resistance and obesity in human and in animal's models.

\section{AIMS}

The aim of this prospective study was to estimate serum concentrations of TNF- $\alpha$ in groups of both normal and hyperlipidemic postmenopausal women and men of appropriate age, to analyze the interrelations between several metabolic variables (including TNF- $\alpha$ ) and factors related to insulin resistance, and to attempt to elucidate the gender differences.

\section{MATERIAL AND METHODS}

Persons in the study. The study was carried out on 70 out-patients of the Metabolic Center at the hospital in Sternberk, Czech Republic. From these, 40 patients (20 men and 20 women) were selected with mild hyperlipidemia i.e. with serum triacylglycerols $3.52 \pm 1.38$ $\mathrm{mmol} / 1$ and HDL-cholesterol $0.96 \pm 0.24 \mathrm{mmol} / 1$ in men and with serum triacylglycerols $2.72 \pm 0.92 \mathrm{mmol} / 1$ and HDL-cholesterol $1.21 \pm 0.21 \mathrm{mmol} / 1$ in women. Lipid criteria were chosen as typical for the early stages of the metabolic syndrome without substantial complications. All patients were treated with antihyperlipidemic drugs (fibrates), some of them received also antihypertensives. None of the patients was known to have had diabetes mellitus. The control groups consisted of 30 persons: ten men with serum triacylglycerols $1.11 \pm 0.44 \mathrm{mmol} / 1$ and HDL- 
cholesterol of $1.34 \pm 0.39 \mathrm{mmol} / 1$, and twenty women serum triacylglycerols $1.42 \pm 0.47 \mathrm{mmol} / 1$ and HDL-cholesterol $1.50 \pm 0.21 \mathrm{mmol} / 1$. No signs of major clinical or laboratory symptoms of other diseases were present in control groups of explored patients. Blood samples were obtained in the morning by a venopuncture after overnight fasting. The serum was separated and stored at -20 ${ }^{\circ} \mathrm{C}$. Informed consent was obtained from all probands.

Biochemical methods. Serum TNF- $\alpha$ concentrations were measured by a sandwich ELISA test kit (Tumor necrosis factor Ultra Sensitive, Human, Cytoscreen US ${ }^{\mathrm{TM}}$ $\mathrm{hTNF}-\alpha$ ). Its sensitivity limit was $0.09 \mathrm{pg} / \mathrm{ml}$, range of 0.5-32 pg/ml, intraassay $\mathrm{CV}<5 \%$, inter-assay $\mathrm{CV}<$ $7 \%$. Tetramethylbenzidine was used as a substrate; quality controls were human based. Several other hormones and peptides were estimated by routine immunochemical tests: insulin, C-peptide (IMMULITE, Diagnostic Products Corporation, Los Angeles, CA, USA), proinsulin intact (DAKO, Denmark). Serum concentration of glucose, total cholesterol, triacylglycerols, HDL-cholesterol, LDL-cholesterol, and uric acid were measured

Table 1. Metabolic characteristics (TAG and HDL-cholesterol) of individual groups

\begin{tabular}{|l|c|c|c|c|c|c|}
\hline & \multicolumn{3}{|c|}{ MEN } & & \multicolumn{3}{c|}{ WOMEN } \\
\cline { 2 - 7 } & $\begin{array}{c}\text { Control } \\
\text { group }\end{array}$ & $\begin{array}{c}\text { Investigated } \\
\text { group }\end{array}$ & $\mathrm{P}$ & $\begin{array}{c}\text { Control } \\
\text { group }\end{array}$ & $\begin{array}{c}\text { Investigated } \\
\text { group }\end{array}$ & $\mathrm{P}$ \\
\hline $\begin{array}{l}\text { Triacylglycerols } \\
(\mathrm{mmol} / \mathrm{l})\end{array}$ & $1.11 \pm 0.44$ & $3.52 \pm 1.38$ & $\mathbf{0 . 0 0 0 1}$ & $1.42 \pm 0.47 *$ & $2.72 \pm 0.92 *$ & $\mathbf{0 . 0 0 0 1}$ \\
\hline $\begin{array}{l}\text { HDL-chol. } \\
(\mathrm{mmol} / \mathrm{l})\end{array}$ & $1.43 \pm 0.39$ & $0.96 \pm 0.24$ & $\mathbf{0 . 0 0 0 3}$ & $1.50 \pm 0.21$ & $\begin{array}{c}1.21 \pm 0.21 \\
* * *\end{array}$ & $\mathbf{0 . 0 0 0 1}$ \\
\hline
\end{tabular}

The statistical significance of differences between the means in the hyperlipidemic and control groups was evaluated using the unpaired t-test. The difference between men and women: $*=p<0.05, * *=p<0.01, * * *=p<0.001$.

Table 2. Detailed characteristics of control and investigated groups

\begin{tabular}{|c|c|c|c|c|c|c|}
\hline & \multicolumn{3}{|c|}{ MEN } & \multicolumn{3}{|c|}{ WOMEN } \\
\hline & $\begin{array}{l}\text { Control } \\
\text { group } \\
\mathrm{N}=10\end{array}$ & $\begin{array}{l}\text { Investigated } \\
\text { group } \\
\mathrm{N}=20\end{array}$ & $P$ & $\begin{array}{l}\text { Control } \\
\text { group } \\
\mathrm{N}=20\end{array}$ & $\begin{array}{l}\text { Investigated } \\
\text { group } \\
\mathrm{N}=20 \\
\end{array}$ & $\mathrm{P}$ \\
\hline Age & $60.3 \pm 11.0$ & $58.6 \pm 10.4$ & 0.69 & $56.9 \pm 13.0$ & $62.0 \pm 7.36$ & 0.15 \\
\hline BMI & $25.91 \pm 3.58$ & $28.51 \pm 2.60$ & 0.030 & $25.6 \pm 3.72$ & $26.73 \pm 3.59$ & 0.24 \\
\hline HOMA IR & $1.685 \pm 0.771$ & $3.137 \pm 1.419$ & $\mathbf{0 . 0 0 2}_{\mathrm{KS}}$ & $1.717 \pm 0.893$ & $2.694 \pm 1.011$ & $\mathbf{0 . 0 0 1}_{\mathrm{KS}}$ \\
\hline QUICKI & $0.3596 \pm 0.0263$ & $0.3266 \pm 0.0185$ & 0.002 & $0.3603 \pm 0.0281$ & $0.3332 \pm 0.0192$ & 0.0007 \\
\hline $\begin{array}{l}\text { Uric acid } \\
(\mathrm{mmol} / \mathrm{l})\end{array}$ & $270.5 \pm 65.4$ & $379.9 \pm 84.2$ & 0.003 & $236.1 \pm 67.0$ & $270.8 \pm 58.9^{* * *}$ & 0.13 \\
\hline $\begin{array}{l}\text { Glycaemia } \\
(\mathrm{mmol} / \mathrm{l})\end{array}$ & $5.31 \pm 0.53$ & $6.11 \pm 0.95$ & $0.029_{\text {KS }}$ & $5.26 \pm 0.42$ & $5.85 \pm 0.70$ & 0.0027 \\
\hline Insulin (mIU/1) & $6.96 \pm 2.80$ & $11.43 \pm 4.50$ & $0.016_{K S}$ & $7.33 \pm 3.80$ & $10.27 \pm 3.52$ & $0.034_{K S}$ \\
\hline $\begin{array}{l}\text { Proinsulin } \\
(\mathrm{pmol} / \mathrm{l})\end{array}$ & $2.68 \pm 1.15$ & $5.51 \pm 2.75$ & $0.012_{\text {К }}$ & $2.51 \pm 1.76$ & $4.49 \pm 3.11$ & $\mathbf{0 . 0 3 4}_{\mathrm{KS}}$ \\
\hline $\begin{array}{l}\text { C-peptide } \\
(\mathrm{nmol} / \mathrm{l})\end{array}$ & $0.66 \pm 0.31$ & $1.11 \pm 0.39$ & 0.0148 & $0.75 \pm 0.35$ & $0.92 \pm 0.34$ & $0.22_{\mathrm{KS}}$ \\
\hline $\begin{array}{l}\text { Cholesterol } \\
(\mathrm{mmol} / \mathrm{l})\end{array}$ & $5.07 \pm 1.06$ & $6.62 \pm 0.82$ & 0.0001 & $5.15 \pm 0.70$ & $6.92 \pm 1.01$ & 0.0001 \\
\hline $\begin{array}{l}\text { LDL } \\
\text { chol.(mmol/1) }\end{array}$ & $3.08 \pm 0.83$ & $4.38 \pm 1.06$ & 0.0047 & $3.21 \pm 0.71$ & $4.74 \pm 1.02$ & 0.0001 \\
\hline TNF- $\alpha(\mathrm{pg} / \mathrm{ml})$ & $14.2 \pm 4.15$ & $11.52 \pm 2.77$ & $0.063_{\mathrm{KS}}$ & $11.65 \pm 6.80$ & $12.73 \pm 9.15$ & $0.43_{\mathrm{KS}}$ \\
\hline
\end{tabular}

The statistical significance of differences between the means in the hyperlipidemic and control groups were evaluated using the unpaired t-test in the case of normal distribution of data sets, and using the Kolmogorov-Smirnov's test when at least in one of the data sets the normal distribution was excluded (labeled by index KS). 
on ILAB-600 biochemical analysator (Instrumentation Laboratory, Lexington, Ma, U.S.A.) using BioVendor sets. All samples were processed and examined according to principles of good laboratory practice and under permanent intralaboratory and external quality control.

Indexes. The homeostatic index of insulin resistance (HOMA IR-Homeostasis Model Assessment) was calculated according to the homeostasis model of assessment $t^{4,5}$ as follows: $H O M A I R=$ fasting insulin $(\mu U / m l) *$ fasting glucose $(\mathrm{mmol} / \mathrm{l}) / 22.5$. The homeostatic index of insulin sensitivity QUICKI (Quantitative Insulin Sensitivity Check Index) was calculated according to Katz et al.6: QUICKI $=1 / \log$ fasting insulin $(\mu U / m l)+\log$ fasting glucose $(\mathrm{mg} / 100 \mathrm{ml})$. Body mass index (BMI), defined as body mass in kilograms divided by the square of height in meters, was calculated.

Statistics. Statistical analysis was performed using the Version 6 SAS/STAT software (SAS Institute, Inc., Cary, NC, U.S.A.). Differences between the means in the hyperlipidemic and control groups were evaluated using unpaired t-test in the case of normal distribution of data sets, and using the Kolmogorov-Smirnov's test when at least in one of the data sets the normal distribution was excluded. Spearman's rank-order correlation and multiple regression analysis were used for correlation analysis. $\mathrm{P}<0.05$ was considered to be of statistical significance. The so called step-down regression model was used to select dominant independent variables. Various four-member groups of independent (explanatory) variables were used for the analysis and the non-zero intercept was taken into account. The independent variables were then dropped, one at a time: at each stage one variable making the least contribution to the dependent variable (i.e. that showed the least p-value in the test of the regression coefficient being zero) was excluded. The coefficient of determination $\mathrm{R}^{2}$ that can be viewed as a percentage explaining the total variance was simultaneously monitored. A great drop in $\mathrm{R}^{2}$ after excluding some independent variable enabled selection of those independent variables that could be considered to be the most important determinants of the dependent variable.

\section{RESULTS}

Table 1 demonstrates metabolic characteristics (TAG and HDL-cholesterol) used as criteria for patient's classification and ranging into the control and investigated groups.

Table 2 shows results of other parameters in control and investigated groups. The age of all four groups did not differ substantially. The value of BMI was increased in the investigated group of men as compared with the controls. The indexes of insulin resistance HOMA IR and QUICKI differed $(\mathrm{p}<0.05)$ in both investigated groups (men and women) as compared with corresponding control groups. Serum uric acid concentration was higher only in hyperlipidemic men as compared with controls. Fasting plasma concentrations of glucose, insulin and intact proinsulin were higher in both investigated groups. Serum concentration of C-peptide was higher only in hyperlipidemic men. LDL-cholesterol differed significantly in both investigated groups. Serum TNF- $\alpha$ concentrations were not different from control groups. In the hypelipidemic men, lower TNF- $\alpha$ was noticed $(p>0.05)$.

From Table 3, presenting 95\% confidence limits of insulin resistance indexes HOMA IR and QUICKI, we concluded that in groups of hyperlipidemic patients of both genders the insulin resistance was substantially higher than in control groups; the groups did not overlap each other.

Table 4 shows the results of Spearman's correlations between individual investigated parameters in investigated and control groups of men. Higher concentration of proinsulin that characterizes increased production of the hormone in the pancreas correlates in insulin-resistant men with higher increase of TNF- $\alpha$ and with lower LDLcholesterol. Higher C-peptide correlates with higher BMI and with lower of HDL-cholesterol.

Women revealed completely different results - Table 5 . In the control group there was positive correlation of serum TNF- $\alpha$ concentrations with proinsulin, positive correlation of LDL-cholesterol with insulin and proinsulin

Table 3. 95\% confidence limits of insulin resistance indexes HOMA IR and QUICKI

\begin{tabular}{|l|c|c|}
\hline \multicolumn{1}{|c|}{ HOMA IR } & $\begin{array}{c}\text { Control } \\
\text { groups }\end{array}$ & $\begin{array}{c}\text { Investigated } \\
\text { groups }\end{array}$ \\
\cline { 1 - 2 } MEN & $\mathbf{1 . 1 6 6 - \mathbf { 2 . 2 0 4 }}$ & $\mathbf{2 . 4 6 1 - \mathbf { 3 . 8 1 3 }}$ \\
\cline { 1 - 2 } $95 \%$ confidence limit & $\mathbf{1 . 2 9 2 - \mathbf { 2 . 1 4 2 }}$ & $\mathbf{2 . 2 1 3 - \mathbf { 3 . 1 7 5 }}$ \\
\cline { 1 - 2 } WOMEN & & \\
\cline { 1 - 2 } $95 \%$ confidence limit & &
\end{tabular}

\begin{tabular}{|l|c|c|}
\hline \multicolumn{1}{|c|}{ QUICKI } & \multicolumn{1}{|c|}{$\begin{array}{c}\text { Control } \\
\text { groups }\end{array}$} & $\begin{array}{c}\text { Investigated } \\
\text { groups }\end{array}$ \\
\hline MEN & $\mathbf{0 . 3 4 1 9 - \mathbf { 0 . 3 7 7 3 }}$ & $\mathbf{0 . 3 1 7 8}-\mathbf{0 . 3 3 5 4}$ \\
\cline { 1 - 3 } 95 confidence limit & $\mathbf{0 . 3 4 6 9 - \mathbf { 0 . 3 7 3 6 }}$ & $\mathbf{0 . 3 2 4 0 - \mathbf { 0 . 3 4 2 3 }}$ \\
\cline { 1 - 2 } WOMEN & & \\
\cline { 1 - 3 } 95 confidence limit & &
\end{tabular}


Table 4. Spearman's correlations between individual parameters in men

MEN - control group

\begin{tabular}{|l|c|c|c|c|c|}
\cline { 2 - 6 } \multicolumn{1}{c|}{} & BMI & TAG & HDL & LDL & TNF- $\alpha$ \\
\hline \multirow{2}{*}{ Insulin } & $\mathrm{Sk}=0.188$ & $\mathrm{Sk}=0.60 *$ & $\mathrm{Sk}=0.006$ & $\mathrm{Sk}=0.428$ & $\mathrm{Sk}=-0.143$ \\
& $\mathrm{p}=0.60$ & $\mathrm{p}=0.066$ & $\mathrm{p}=0.99$ & $\mathrm{p}=0.29$ & $\mathrm{p}=0.736$ \\
\hline \multirow{2}{*}{ HOMA IR } & $\mathrm{Sk}=0.248$ & $\mathrm{Sk}=0.515$ & $\mathrm{Sk}=0.006$ & $\mathrm{Sk}=0.428$ & $\mathrm{Sk}=-0.119$ \\
& $\mathrm{p}=0.49$ & $\mathrm{p}=0.13$ & $\mathrm{p}=0.85$ & $\mathrm{p}=0.29$ & $\mathrm{p}=0.778$ \\
\hline \multirow{2}{*}{ Proinsulin } & $\mathrm{Sk}=-0.479$ & $\mathrm{Sk}=\mathbf{0 . 7 3 3}$ & $\mathrm{Sk}=-0.479$ & $\mathrm{Sk}=-0.047$ & $\mathrm{Sk}=0.357$ \\
& $\mathrm{p}=0.16$ & $\mathbf{P}=\mathbf{0 . 0 2}$ & $\mathrm{p}=0.16$ & $\mathrm{p}=0.91$ & $\mathrm{p}=0.385$ \\
\hline \multirow{2}{*}{ C-Peptide } & $\mathrm{Sk}=0.257$ & $\mathrm{Sk}=0.143$ & $\mathrm{Sk}=0.428$ & $\mathrm{Sk}=0.400$ & $\mathrm{Sk}=0.428$ \\
& $\mathrm{p}=0.62$ & $\mathrm{P}=0.79$ & $\mathrm{p}=0.40$ & $\mathrm{p}=0.60$ & $\mathrm{p}=0.396$ \\
\hline \multirow{2}{*}{ TNF- $\alpha$} & $\mathrm{Sk}=-0.476$ & $\mathrm{Sk}=0.095$ & $\mathrm{Sk}=-0.047$ & $\mathrm{Sk}=0.314$ & - \\
& $\mathrm{p}=0.233$ & $\mathrm{P}=0.822$ & $\mathrm{p}=0.918$ & $\mathrm{p}=0.544$ & - \\
\hline
\end{tabular}

MEN - investigated group

\begin{tabular}{|l|c|c|c|c|c|}
\cline { 2 - 6 } \multicolumn{1}{c|}{} & BMI & TAG & HDL & LDL & TNF- $\alpha$ \\
\hline Insulin & $\mathrm{Sk}=0.166$ & $\mathrm{~S}=-0.257$ & $\mathrm{Sk}=-0.237$ & $\mathrm{Sk}=-0.001$ & $\mathrm{Sk}=-0.286$ \\
& $\mathrm{p}=0.48$ & $\mathrm{P}=0.27$ & $\mathrm{p}=0.31$ & $\mathrm{P}=1.0$ & $\mathrm{p}=0.220$ \\
\hline \multirow{2}{*}{ HOMA IR } & $\mathrm{Sk}=0.358$ & $\mathrm{Sk}=-0.278$ & $\mathrm{Sk}=-0.180$ & $\mathrm{Sk}=-0.057$ & $\mathrm{Sk}=-0.235$ \\
& $\mathrm{p}=0.12$ & $\mathrm{P}=0.24$ & $\mathrm{p}=0.45$ & $\mathrm{p}=0.99$ & $\mathrm{p}=0.317$ \\
\hline \multirow{2}{*}{ Proinsulin } & $\mathrm{Sk}=0.406$ & $\mathrm{Sk}=0.129$ & $\mathrm{Sk}=-0.362$ & $\mathrm{Sk}=\mathbf{- 0 . 5 4 3}$ & $\mathbf{S k}=\mathbf{0 . 4 5 9}$ \\
& $\mathrm{p}=0.075$ & $\mathrm{p}=0.59$ & $\mathrm{p}=0.12$ & $\mathbf{p}=\mathbf{0 . 0 1 3}$ & $\mathbf{p}=\mathbf{0 . 0 4 1}$ \\
\hline \multirow{2}{*}{ C-peptide } & $\mathrm{Sk}=\mathbf{0 . 5 6 2}$ & $\mathrm{Sk}=0.249$ & $\mathrm{Sk}=-0.432$ & $\mathrm{Sk}=-0.192$ & $\mathrm{Sk}=-0.010$ \\
& $\mathbf{p}=\mathbf{0 . 0 0 9 8}$ & $\mathrm{p}=0.288$ & $\mathrm{p}=0.057 *$ & $\mathrm{p}=0.417$ & $\mathrm{p}=0.964$ \\
\hline TNF- $\alpha$ & $\mathrm{Sk}=0.262$ & $\mathrm{Sk}=0.162$ & $\mathrm{Sk}=0.120$ & $\mathrm{Sk}=-0.271$ & - \\
& $\mathrm{p}=0.263$ & $\mathrm{p}=0.493$ & $\mathrm{p}=0.614$ & $\mathrm{p}=0.247$ & - \\
\hline
\end{tabular}

Significant corelations are printed in bold. TAG $=$ triacylglycerols.

Table 5. Spearman's correlations between individual parameters in women

WOMEN - control group

\begin{tabular}{|l|c|c|c|c|c|}
\cline { 2 - 6 } \multicolumn{1}{c|}{} & BMI & TAG & HDL & LDL & TNF- $\alpha$ \\
\hline \multirow{2}{*}{ Insulin } & $\mathrm{Sk}=0.399$ & $\mathrm{Sk}=0.169$ & $\mathbf{S k}=\mathbf{- 0 . 4 9 8}$ & $\mathbf{S k}=\mathbf{0 . 5 2 3}$ & $\mathrm{Sk}=0.269$ \\
& $\mathrm{p}=0.807$ & $\mathrm{p}=0.48$ & $\mathbf{p}=\mathbf{0 . 0 2 5}$ & $\mathbf{p}=\mathbf{0 . 0 3 7}$ & $\mathrm{p}=0.373$ \\
\hline \multirow{2}{*}{ HOMA IR } & $\mathrm{Sk}=0.354$ & $\mathrm{Sk}=0.157$ & $\mathbf{S k}=\mathbf{- 0 . 4 9 9}$ & $\mathrm{Sk}=0.393$ & $\mathrm{Sk}=0.225$ \\
& $\mathrm{p}=0.13$ & $\mathrm{p}=0.51$ & $\mathbf{p}=\mathbf{0 . 0 2 5}$ & $\mathrm{p}=0.13$ & $\mathrm{p}=0.459$ \\
\hline \multirow{2}{*}{ Proinsulin } & $\mathrm{Sk}=0.163$ & $\mathrm{Sk}=0.009$ & $\mathrm{Sk}=-0.243$ & $\mathbf{S k}=\mathbf{0 . 5 6 3}$ & $\mathbf{S k}=\mathbf{0 . 6 2 1}$ \\
& $\mathrm{p}=0.49$ & $\mathrm{p}=0.97$ & $\mathrm{p}=0.30$ & $\mathbf{p}=\mathbf{0 . 0 2 3}$ & $\mathbf{p}=\mathbf{0 . 0 2 3 5}$ \\
\hline \multirow{2}{*}{ C-peptide } & $\mathrm{Sk}=0.176$ & $\mathrm{Sk}=0.332$ & $\mathrm{Sk}=-0.356$ & $\mathrm{Sk}=0.027$ & $\mathrm{Sk}=0.423$ \\
& $\mathrm{p}=0.60$ & $\mathrm{p}=0.32$ & $\mathrm{p}=0.28$ & $\mathrm{p}=0.95$ & $\mathrm{p}=0.194$ \\
\hline TNF- $\alpha$ & $\mathrm{Sk}=-0.165$ & $\mathrm{Sk}=-0.187$ & $\mathrm{Sk}=-0.206$ & $\mathrm{Sk}=0.042$ & - \\
& $\mathrm{p}=0.589$ & $\mathrm{p}=0.541$ & $\mathrm{p}=0.499$ & $\mathrm{p}=0.945$ & - \\
\hline
\end{tabular}

WOMEN - investigated group

\begin{tabular}{|l|c|c|c|c|c|}
\cline { 2 - 6 } \multicolumn{1}{c|}{} & BMI & TAG & HDL & LDL & TNF- $\alpha$ \\
\hline \multirow{2}{*}{ Insulin } & $\mathrm{Sk}=0.261$ & $\mathrm{Sk}=0.292$ & $\mathrm{Sk}=\mathbf{- 0 . 5 2 0}$ & $\mathrm{Sk}=-0.046$ & $\mathbf{S k}=\mathbf{0 . 5 1 8}$ \\
& $\mathrm{p}=0.27$ & $\mathrm{p}=0.21$ & $\mathbf{p}=\mathbf{0 . 0 1 8}$ & $\mathrm{p}=0.85$ & $\mathbf{p}=\mathbf{0 . 0 1 9}$ \\
\hline \multirow{2}{*}{ HOMA IR } & $\mathrm{Sk}=0.308$ & $\mathrm{Sk}=0.334$ & $\mathbf{S k}=\mathbf{- 0 . 5 5 4}$ & $\mathrm{Sk}=-0.111$ & $\mathbf{S k}=\mathbf{0 . 4 4 7}$ \\
& $\mathrm{p}=0.19$ & $\mathrm{p}=0.15$ & $\mathbf{p}=\mathbf{0 . 0 1 1}$ & $\mathrm{p}=0.85$ & $\mathbf{p}=\mathbf{0 . 0 4 8}$ \\
\hline \multirow{2}{*}{ Proinsulin } & $\mathrm{Sk}=-0.052$ & $\mathrm{Sk}=0.391$ & $\mathbf{S k}=\mathbf{- 0 . 5 1 6}$ & $\mathrm{Sk}=-0.207$ & $\mathrm{Sk}=-0.083$ \\
& $\mathrm{p}=0.83$ & $\mathrm{p}=0.08 \mathbf{p}^{*}$ & $\mathbf{p}=\mathbf{0 . 0 1 9}$ & $\mathrm{p}=0.38$ & $\mathrm{p}=0.728$ \\
\hline \multirow{2}{*}{ C-Peptide } & $\mathrm{Sk}=0.424$ & $\mathrm{Sk}=0.230$ & $\mathrm{Sk}=-0.473$ & $\mathrm{Sk}=-0.314$ & $\mathbf{S k}=\mathbf{0 . 6 3 5}$ \\
& $\mathrm{p}=0.13$ & $\mathrm{p}=0.43$ & $\mathrm{p}=0.087 *$ & $\mathrm{p}=0.27$ & $\mathbf{p}=\mathbf{0 . 0 1 5}$ \\
\hline TNF- $\alpha$ & $\mathrm{Sk}=0.292$ & $\mathrm{Sk}=-0.249$ & $\mathrm{Sk}=-0.191$ & $\mathrm{Sk}=0.054$ & - \\
& $\mathrm{p}=0.210$ & $\mathrm{p}=0.289$ & $\mathrm{p}=0.402$ & $\mathrm{p}=0.820$ & - \\
\hline
\end{tabular}

Statistical significant correlations are printed in bold. 
Table 6. Multiple regression analysis of data from men (control and investigated group)

\begin{tabular}{|c|c|c|c|c|c|c|c|}
\hline \multirow{9}{*}{ 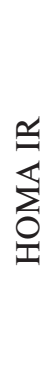 } & & Intercept & BMI & TNF- $\alpha$ & HDL & TAG & R2 \\
\hline & Par. & 0.2051 & 0.1739 & -0.0394 & -1.4657 & -0.0718 & 0.2723 \\
\hline & $\mathrm{T}=0$ & 0.9387 & 0.0557 & 0.6252 & 0.0948 & 0.7014 & \\
\hline & Par. & 0.1474 & 0.1640 & -0.0435 & -1.2993 & & 0.2675 \\
\hline & $\mathrm{T}=0$ & 0.9550 & 0.0541 & 0.5800 & 0.0800 & & \\
\hline & Par. & -0.8453 & 0.1878 & & -1.5211 & & 0.3198 \\
\hline & $\mathrm{T}=0$ & 0.6952 & 0.0153 & & 0.0214 & & \\
\hline & Par. & -2.5479 & 0.1882 & & & & 0.1696 \\
\hline & $\mathrm{T}=0$ & 0.2543 & 0.0238 & & & & \\
\hline
\end{tabular}

\begin{tabular}{|c|c|c|c|c|c|c|c|}
\hline \multirow{9}{*}{ 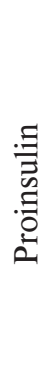 } & & Intercept & BMI & TNF- $\alpha$ & HDL & TAG & $\mathrm{R} 2$ \\
\hline & Par. & -1.5326 & 0.2833 & 0.2385 & -4.3256 & 0.0649 & 0.4246 \\
\hline & $\mathrm{T}=0$ & 0.7322 & 0.0626 & 0.0870 & 0.0055 & 0.8361 & \\
\hline & Par. & -1.4805 & 0.2923 & 0.2422 & -4.4760 & & 0.4235 \\
\hline & $\mathrm{T}=0$ & 0.7354 & 0.0412 & 0.0739 & 0.0010 & & \\
\hline & Par. & 1.5474 & 0.2659 & & -3.8953 & & 0.3819 \\
\hline & $\mathrm{T}=0$ & 0.6865 & 0.0488 & & 0.0016 & & \\
\hline & Par. & 8.9041 & & & -3.9003 & & 0.2844 \\
\hline & $\mathrm{T}=0$ & 0.0001 & & & 0.0024 & & \\
\hline
\end{tabular}

\begin{tabular}{|c|c|c|c|c|c|c|c|}
\hline & & Intercept & BMI & TNF- $\alpha$ & HDL & TAG & R2 \\
\cline { 2 - 8 } & Par. & -1.1517 & 0.0864 & -0.0038 & -0.3115 & 0.0449 & $\mathbf{0 . 5 6 8 3}$ \\
\cline { 2 - 8 } & $\mathrm{T}=0$ & 0.0897 & $\mathbf{0 . 0 0 0 7}$ & 0.8627 & 0.1273 & 0.3190 & \\
\cline { 2 - 8 } & Par. & -1.1967 & 0.0867 & & -0.3176 & 0.0436 & $\mathbf{0 . 5 6 7 7}$ \\
\cline { 2 - 8 } & $\mathrm{T}=0$ & 0.0514 & $\mathbf{0 . 0 0 0 4}$ & & 0.1066 & 0.3149 & \\
\cline { 2 - 8 } & Par. & -1.1955 & 0.0942 & & -0.3915 & & $\mathbf{0 . 5 4 6 9}$ \\
\cline { 2 - 8 } & $\mathrm{T}=0$ & 0.0513 & $\mathbf{0 . 0 0 0 1}$ & & $\mathbf{0 . 0 3 5 0}$ & & $\mathbf{0 . 4 4 8 0}$ \\
\cline { 2 - 8 } & Par. & -1.6087 & 0.0943 & & & & \\
\end{tabular}

Par. = coefficient of regression, $T=0$ probability $(p)$ that value of regression coefficient is zero. $R^{2}=$ coefficient of determination, explaining the degree of influence dependent variable by independent variables.

and negative correlation of HDL-cholesterol with insulin and HOMA IR. We also found positive correlation of TNF- $\alpha$ with insulin, HOMA IR and C-peptide and negative correlation of HDL-cholesterol with insulin, HOMA IR and intact proinsulin. In both genders, the insulin resistance in persons with mild symptoms of metabolic syndrome correlated with serum TNF- $\alpha$ and with HDLcholesterol. In the group of men it also correlated with LDL-cholesterol.

We also performed the multiple regression analysis of relations between important parameters characterizing insulin resistance (HOMA IR, intact proinsulin and C-peptide) as dependent variables and metabolic parameters (BMI, TNF- $\alpha$, HDL-cholesterol and triacylglycerols) as independent variables. We have especially tried to find differences in the pathogenesis of insulin resistance between men and women. In respect to general character of these relations, which come across in regulation of degree of insulin resistance in people without metabolic syndrome, and with respect to necessary number in individual groups, we analyzed all men and women (the control and investigated group) together.
Table 6 demonstrates the results of multiple regression analysis in the group of men. BMI and HDL-cholesterol seemed to play a main role in influencing the insulin resistance index HOMA IR, while TNF- $\alpha$ and triacylglycerols failed to show any significant role. Serum proinsulin concentrations were mostly influenced by HDL-cholesterol and by BMI. In the case of serum C-peptide concentration as dependent variable, the situation in the group of men was similar to the case of HOMA IR: BMI and HDL-cholesterol played a dominant role. The BMI and the HDLcholesterol influenced the serum C-peptide concentration in $55 \%$. An increase in BMI itself influenced the serum C-peptide concentration in $45 \%$.

The situation in women was completely different Table 7. The dominant independent variable influencing HOMA IR was serum triacylglycerol concentration. Serum concentration of intact proinsulin was also mostly influenced by concentration of triacylglycerols, especially in combination with HDL-cholesterol. The effect of TNF- $\alpha$ and BMI was not important. C-peptide concentration as dependent variable was dominantly influenced by HDLcholesterol. HDL-cholesterol concentrations and TNF- $\alpha$ 
Table 7. Multiple regression analysis of data from women (control and investigated group)

\begin{tabular}{|c|c|c|c|c|c|c|c|}
\hline & & Intercept & BMI & TNF- $\alpha$ & HDL & TAG & $\mathbf{R}^{2}$ \\
\cline { 2 - 7 } & Par. & 0.7812 & 0.0507 & 0.0565 & -0.9526 & 0.4160 & $\mathbf{0 . 6 4 6 3}$ \\
\cline { 2 - 7 } & $\mathrm{T}=0$ & 0.6208 & 0.1770 & $\mathbf{0 . 0 0 0 8}$ & 0.1413 & $\mathbf{0 . 0 0 8 1}$ & \\
\cline { 2 - 7 } & Par. & 2.3248 & & 0.0538 & 1.1530 & 0.4564 & $\mathbf{0 . 6 2 2 0}$ \\
\cline { 2 - 7 } & $\mathrm{T}=0$ & 0.0453 & & $\mathbf{0 . 0 0 1 3}$ & 0.0740 & $\mathbf{0 . 0 0 3 8}$ & \\
\cline { 2 - 7 } & Par. & 0.3636 & & 0.0624 & & 0.6127 & $\mathbf{0 . 5 7 7 3}$ \\
\cline { 2 - 8 } & $\mathrm{T}=0$ & 0.3111 & & $\mathbf{0 . 0 0 0 2}$ & & $\mathbf{0 . 0 0 0 1}$ & $\mathbf{0 . 3 6 6 4}$ \\
\cline { 2 - 8 } & Par. & 0.7954 & & & & $\mathbf{0 . 0 0 0 1}$ & \\
\cline { 2 - 7 } & $\mathrm{T}=0$ & 0.0223 & & & & & \\
\hline
\end{tabular}

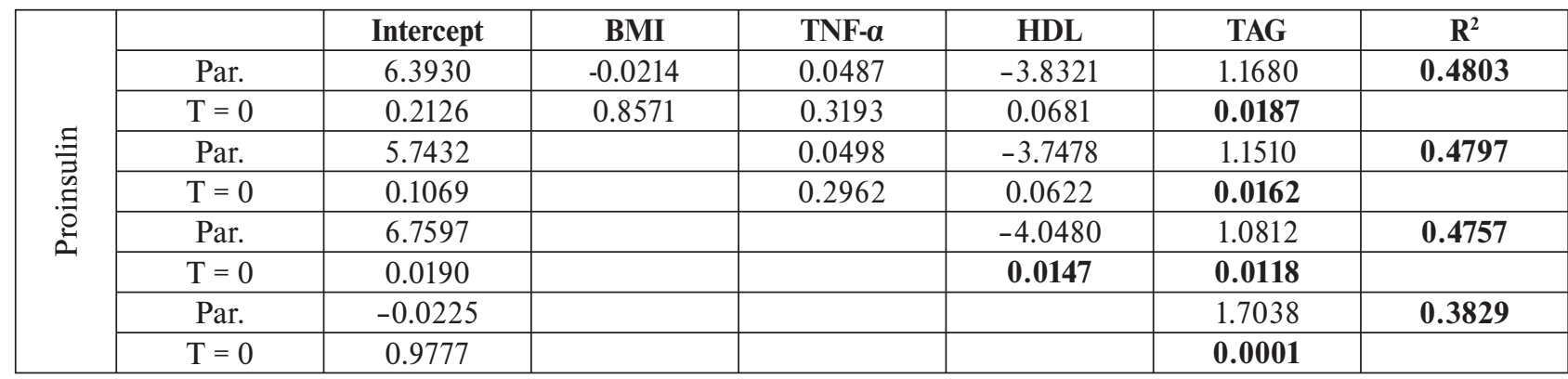

\begin{tabular}{|c|c|c|c|c|c|c|c|}
\hline \multirow{9}{*}{ 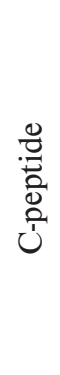 } & & Intercept & BMI & TNF- $\alpha$ & HDL & TAG & $\mathbf{R}^{2}$ \\
\hline & Par. & 0.8116 & 0.0111 & 0.0283 & -0.5344 & 0.0494 & 0.4748 \\
\hline & $\mathrm{T}=0$ & 0.3295 & 0.5271 & 0.0172 & 0.1512 & 0.4964 & \\
\hline & Par. & 1.1555 & & 0.0278 & -0.5822 & 0.0564 & 0.4639 \\
\hline & $\mathrm{T}=0$ & 0.0690 & & 0.0167 & 0.1067 & 0.4260 & \\
\hline & Par. & 1.5414 & & 0.0268 & -0.7730 & & 0.4471 \\
\hline & $\mathrm{T}=0$ & 0.0004 & & 0.0187 & $\mathbf{0 . 0 0 5 5}$ & & \\
\hline & Par. & 1.9476 & & & -0.8410 & & 0.2850 \\
\hline & $\mathrm{T}=0$ & 0.0001 & & & 0.0060 & & \\
\hline
\end{tabular}

Par. $=$ parameter (coefficient of regression), $\mathrm{T}=0$ probability $(\mathrm{p})$ that value of regression coefficient is zero.

$\mathrm{R}^{2}=$ coefficient of determination, explaining the degree of influence dependent variable by independent variables.

concentrations influenced the C-peptide concentration in $44 \%$. HDL-cholesterol itself influenced C-peptide concentrations in $28 \%$.

\section{DISCUSSION}

The key role of TNF- $\alpha$ in the genesis of insulin resistance has been reported in humans and in animal models especially in relation to obesity associated with diabetes type 2 . In the fatty tissue of obese animals with insulin resistance and type 2 diabetes, the TNF- $\alpha$ concentration is elevated ${ }^{7}$. Neutralization of TNF- $\alpha$ in vivo dramatically increased the insulin sensitivity of these obese animals, resulting in increased glucose uptake in peripheral tissues. These observations confirmed the role of TNF- $\alpha$ as a key mediator of insulin resistance in obesity. Similarly in vitro, chronic exposition of adipocytes to low concentration of TNF- $\alpha$ caused strong inhibition of insulin stimulated glucose uptake in peripheral tissues ${ }^{8,9}$.

Mishima et al. found that the serum TNF- $\alpha$ concentration in obese persons with type 2 diabetes depends on the degree of their insulin resistance but does not depend on $\mathrm{BMI}^{10}$. On the other hand Bertin et al. detected a correlation between TNF- $\alpha$ and BMI with indexes of intra-abdominal fat tissue, but not with glycaemia or the total amount of fatty mass in the body ${ }^{11}$. In morbidly obese women $(\mathrm{BMI}>40)$ insulin resistance correlated positively with TNF- $\alpha$ expression and inversely with the glucose transporter protein GLUT-4 expression in muscle cells ${ }^{12}$. In obese women there was an excessive expression of TNF- $\alpha$ in adipose tissue, which was proportional to the amount of fat depots and was not dependent on presence or absence of diabetes.

TNF- $\alpha$ expression correlated negatively with the activity of lipoprotein lipase and positively with $\mathrm{BMI}^{13}$. Miyazaki et al. compared groups of obese patients without diabetes, patients with glucose intolerance and patients with type 2 diabetes. In contradiction with the previous study, serum TNF- $\alpha$ concentration in obese persons with diabetes was higher than in patients with or without glucose intolerance. Serum TNF- $\alpha$ concentrations correlated positively with fasting plasma glucose and insulin in healthy persons and in persons with glucose intolerance, 
but not in persons with diabetes. In the former groups the critical predictors of insulin mediated glucose uptake were BMI and serum TNF- $\alpha$ only. In persons with diabetes it was only fasting plasma glucose and insulin. The authors concluded that increase in the circulated TNF- $\alpha$ was associated with both, increase in insulin resistance in peripheral tissues and the increase in glycaemia before the appearance of type 2 diabetes. The subsequent increase in insulin resistance in patients with type 2 diabetes is not associated with increase in serum TNF- $\alpha$ concentration ${ }^{14}$.

The increase in serum TNF- $\alpha$ concentration and its expression is related to obesity and the amount of fat tissue. There is also a relation between TNF- $\alpha$ and the development of type 2 diabetes. The question arises whether TNF- $\alpha$ is a factor influencing the development of insulin resistance before the appearance of its clinical symptoms.

Even though tested persons were not obese and they did not have type 2 diabetes, we found increased insulin resistance in both investigated gender groups. This was confirmed not only by the highly significant homeostatic indexes of insulin resistance and by no overlapping 95\% confidence limits of these indexes, but also by the significant increase in fasting plasma concentration of glucose, triacylglycerols, insulin and proinsulin. In men there was also an increase in urine acid and C-peptide. In both genders there was decrease in serum HDL-cholesterol concentration in comparison with control group (Table 1 and 2).

In hyperlipidemic men the average values of TNF- $\alpha$ concentration decreased, in hyperlipidemic women these values insignificantly increased. The Spearman's correlations in investigated men demonstrated only an association between TNF- $\alpha$ and proinsulin. In women this association was already present in the control group. In hyperlipidemic women this association disappeared. However there was a significant association between TNF- $\alpha$ and serum insulin concentration, HOMA IR and C-peptide.

The serum TNF- $\alpha$ concentration was associated with the serum proinsulin concentrations in women without insulin resistance and in men with increased insulin resistance, but it was significantly associated with increase in insulin resistance in women, which manifested as correlation of TNF- $\alpha$ with HOMA IR and with serum concentrations of insulin and C-peptide. Neither in control nor in investigated group of men did we find significant correlations between TNF- $\alpha$ and index of insulin resistance, while the investigated group of women showed significant association of TNF- $\alpha$ with insulin resistance (with index HOMA IR, serum concentration of insulin and C-peptide). From our observations it can be concluded that TNF- $\alpha$ plays an important role in the development of insulin resistance in men and women with early symptoms of insulin resistance in a different way.

Some papers have reported on the gender differences in the genesis of insulin resistance and metabolic syndrome. Our data differ from the results of Nilsson et al, who showed increased serum TNF- $\alpha$ concentrations in elderly diabetic men, which significantly correlated with BMI, fasting plasma glucose, triacylglycerols, and negatively correlated with serum HDL-cholesterol ${ }^{15}$. In our study, the symptoms of insulin resistance in the group of investigated men were less expressed. In the study of Tsigos et al. comparison of the TNF- $\alpha$ levels in obese and non-obese women was studied. TNF- $\alpha$ was increased only in the obese women, who had impaired glucose tolerance. TNF- $\alpha$ in these women significantly correlated with index of their waist/hip ratio and with P-glucose concentration after glucose load, but not with $\mathrm{BMI}^{16}$. Corica et al. found more increased serum TNF- $\alpha$ concentrations in women than in men and this was found both in control groups and in obese persons ${ }^{17}$. In our non-obese but insulin resistant subjects the serum TNF- $\alpha$ levels did not significantly differ between non-obese and obese men and women, but in women the serum TNF- $\alpha$ concentrations correlated with the symptoms of insulin resistance.

Also in another study on relatively young men $(<45$ years) with early myocardial infarction, the TNF- $\alpha$ concentrations were increased in comparison with controls, but did not correlate with the degree of insulin resistance. On the other hand they correlated positively with triacylglycerols and inversely with HDL-cholesterol ${ }^{18}$. TNF- $\alpha$ expression of abdominal adipose fat tissue was increased only in morbidly obese men. It correlated with BMI and did not correlate with the degree of insulin resistance ${ }^{19}$. In the native Canadian population with a higher prevalence of type 2 diabetes no differences between men and women regarding the serum TNF- $\alpha$ concentration were found. Correlations between TNF- $\alpha$ and fasting plasma concentration of insulin and triacylglycerols, HOMA index, waist, and blood pressure were more distinct in women than in $\operatorname{men}^{20}$.

Bastard et al. reported that in non-diabetic and diabetic women with android obesity and increased insulin resistance the serum TNF- $\alpha$ concentration is increased (together with increase of IL-6 and leptin). Application of low-caloric diet did not cause a significant decrease of serum TNF- $\alpha$ and did not lead to a decrease of TNF $\alpha$ concentration in abdominal subcutaneous fat tissue. IL- 6 and leptin concentrations were decreased in this tissue ${ }^{21}$.

The question arises whether the TNF- $\alpha$ expression and serum TNF- $\alpha$ are just a result of obesity or could be present in non obese persons regardless the gender? In our investigated group of men the BMI increased significantly, but the mean concentration of TNF- $\alpha$ did not increase (conversely it insignificantly decreased). Analysis of correlation did not reflect a association between TNF $\alpha$ and insulin resistance. We cannot confirm the reports on the crucial role of TNF- $\alpha$ in the genesis of insulin resistance in men.

In our investigated group of women the BMI did not differ from the control group. The mean serum TNF- $\alpha$ increased only insignificantly, however it correlated with the HOMA IR, serum insulin and C-peptide. TNF- $\alpha$ may, though play some role in the development of insulin resistance in women (independently of BMI). 
We assume that conditions for the genesis of insulin resistance differ in the early stages of the development of this phenomenon both in men and women. The role of TNF- $\alpha$ is bigger in women and does not necessarily have to be associated with increase in obesity. Increase in obesity evidently causes emphasis on the role of the TNF $\alpha$ in these processes, similarly in men and women. Hube and Hauner concluded that excessive expression of TNF- $\alpha$ especially in the subcutaneous fat depots induces an increase in insulin resistance in peripheral tissues (especially in the muscles) by the mechanisms described above. System TNF- $\alpha$ represents an important physiological mechanism of the body defense against increase in body mass ${ }^{22}$. Some data reflecting the inhibitive effect of TNF- $\alpha$ on the production of leptin in the adipocytes of the obese persons supported the above concept ${ }^{23}$.

From our results it can be seen that this mechanism is more evolved in women, and that it can work without excessive fat accumulation in body. Serum TNF- $\alpha$ concentrations increased in non-obese women with ovarium's polycystic syndrome, as well as $i^{24}$, healthy relatives descendants of parents with type 2 diabetes ${ }^{25}$. Serum TNF- $\alpha$ also increased during normal pregnancy ${ }^{26}$. These facts reflect the role of this factor in the etiopathogenesis of insulin resistance, which is not necessarily associated with diabetes mellitus or obesity.

On the other hand Koistinen et al. deny any association whatever between insulin sensitivity and mRNA-TNF $\alpha$ expression in the subcutaneous adipose tissue of obese persons with and without diabetes. This association was only found in morbidly obese men ${ }^{19}$. Bluher et al. also do not accept the role of TNF- $\alpha$ in the genesis of the early stages of insulin resistance. On the basis of the studies of the patients with glucose intolerance, they attributed the genesis of insulin resistance to non esterified fatty acids in particular ${ }^{27}$. Demirbas et al. discovered that in patients with hypertension serum TNF- $\alpha$ concentrations increase together with increase in concentrations of insulin, triacylglycerols, and HOMA IR. No correlations were found between the insulin resistance and concentration of TNF- $\alpha^{28}$. Norberg et al. based on a prospective study in 33336 persons, assumed that from molecules secreted by fat tissue only leptin but not TNF- $\alpha$, free fatty acids or IL-6, is a risk marker of development for type 2 diabetes which is not associated with obesity ${ }^{29}$. Pathogenetic principle of diabetes type 2 is an increase in insulin resistance ${ }^{30}$.

Substantial differences between men and women in relation to the genesis of the insulin resistance have been found. In men, BMI and HDL-cholesterol in the serum play the crucial role in influencing insulin resistance. The higher BMI the higher is insulin resistance. On the other hand the inverse dependence between serum HDL-cholesterol and insulin resistance is rare. Robins et al in prospective study on more then 2000 men with increase in triacylglycerols and decrease HDL-cholesterol (in a group similar to our investigated group of men), found that the development of cardiovascular complications is more of- ten associated with the presence or the absence of insulin resistance than with the decrease in HDL-cholesterol, even though the low HDL-cholesterol in insulin resistant men was constantly present ${ }^{31}$. This is in accordance to our results. The dominant factor is BMI. The effect of TNF- $\alpha$ and triacylglycerols on insulin resistance is not significant.

Similar associations exist between serum concentrations of $\mathrm{C}$ peptide and independent variables. Serum concentration of proinsulin is more influenced by HDLcholesterol than by BMI. Hanley et al. examined associations between proinsulin concentration and abdominal adiposity in the original people of Canada with high risk of diabetes type 2. Proinsulin was higher in diabetics in comparison with the non-diabetic persons. Proinsulin concentration correlated with the percentage of the body fat, BMI and waist. The results reflected the unfavorable influence of abdominal adiposity on the function of B cells in the pancreas already at the beginning of the development of glucose intolerance ${ }^{32}$. Our result may specify that together with the increase in BMI also decrease in HDL-cholesterol participate on this process.

In women, serum triacylglycerols together with increased TNF- $\alpha$ play a dominant role in the development of insulin resistance, while the influence of the low HDLcholesterol and high BMI is not significant. The influence of HDL-cholesterol together with TNF- $\alpha$ is more important in the regulation of the serum concentration of C-peptide, while in the regulation of proinsulin triacylglycerols play the most important role.

\section{CONCLUSION}

The individual parameters related to insulin resistance (the HOMA IR, the formation of insulin in cells and its release into circulation) are influenced by investigated metabolic factors and TNF- $\alpha$ in a different way. This effect is different in relation to the gender. In women the grade of insulin resistance is very considerably influenced by serum triglycerides, TNF- $\alpha$ and by decreased concentration of HDL-cholesterol, while in men a influence of BMI and decreased HDL- cholesterol is observed.

\section{ACKNOWLEDGMENT}

This study was supported by the research project of the Ministry of Education, Youth and Sport, Czech Republic MSM 151100005.

\section{REFERENCES}

1. Ford ES, Giles WH, Dietz WH. (2002) P revalence of the metabolic syndrome among US adults. JAMA. 287, 356-359.

2. Svačina Š. (Editor) (2002) Metabolický syndrom, Triton.

3. Beckman JA, Creager MA, Libby P. (2002) Diabetes and atherosklerosis, epidemiology, pathofysiology, and management. JAMA. 287, 2570-2581. 
4. Matthews DR, Hosker JP, Rudenski AS, Naylor BA, Treacher DF, Turner RC. (1985) Homeostasis model assessment: insulin resistance and beta-cell function from fasting plasma glucose and insulin concentrations in man. Diabetologiea 28, 412-9.

5. Haffner SM, Miettinen H, Stern MP. (1997) The homeostasis model in the San Antonio Heart Study. Diabetes Care. 20, 1087-92.

6. Katz A, Nambi SS, Mather K, Baron AD, Follmann DA, Sullivan G, Quon MJ. (2000) Quantitative insulin sensitivity check index: a simple, accurate method for assessing insulin sensitivity in humans. J Clin Endocrinol Metab. 85, 2402-10.

7. Hotamisligil GS, Shargill NS, Spiegelman BM. (1993) Adipose expression of tumor necrosis factor-alpha: direct role in obesitylinked insulin resistance. Science. 259, 87-91.

8. Hotamisligil GS, Budavari A, Murray D, Spiegelman BM. (1994) Reduced tyrosine kinase activity of the insulin recptor in obesitydiabetes. Central role of tumor necrosis factor-alpha. J Clin Invest. 94, 1543-1549.

9. Hotamisligil GS, Arner P, Caro JF, Atkinson RL, Spiegelman BM. (1995) Increased adipose tissue expression of tumor necrosis factor-alpha in human obesity and insulin resistance. J Clin Invest. 95 2409-2415.

10. Mishima Y, Kuyama A, Tada A, Takahashi K, Ishioka T, Kibata M. (2001) Relationship between tutmor necrosis factor- $\alpha$ and insulin resistance in obese men with type 2 diabetes mellistus. Diabetes Res Clin Pract. 52, 119-1 23.

11. Bertin E, Nguyen P, Guenounou M, Durlach V, Potron G, Leutenegger M. (2000) Plasma levels of tumor necrosis factor-alpha (TNF-alpha) are essentially dependent on visceral fat amount in type 2 diabetic patients. Diabetes Metab. 26, 178-182.

12. Mingrone G, Rosa G, Di Rocco P, Manco M, Capristo E, Castagneto M, Vettor R, Gasbarrini G, Greco AV. (2002) Skeletal muscle triglyceride lowering in associated with net improvement of insulin sensitivity, TNF-alpha reduction and GLUT 4 expression enhancement. Int J Obes Relat Metab Disord. 26, 1165-1172.

13. Bullo M, Garcia-Lorda P, Peinado-Onsurbe J, Hernandez M, Del Castillo D, Argiles JM, Salas-Salvado J. (2002) TNFalpha expression of subcutaneous adipose tissue in obese and morbid obese females: relationship to adipocyte LPL activity and leptin synthesis. Int J Obes Metab Disord. 26, 652-658.

14. Miyazaki Y, Pipek R, Mandarino LJ, DeFronzo RA. (2003) Tumor necrosis factor alpha and insulin resistance in obese type 2 diabetic patients. Int J Obes. 27, 88-94.

15. Nilsson J, Jovinge S, Niemann A, Reneland R, Lithell H (1998) Relation between plasma tumor necrosis factor-alpha and insulin sensitivity in elderly men with non-insulin-dependent diabetes mellitus. Arterioscler Thromb Vasc Biol. 18, 1199-1202.

16. Tsigos C, Kyrou I, Chala E, Tsapogas P, Stavridis JC, Raptis SA, Katsilambros N. (1999) Circulating tumor necrosis alpha concentrations are higher in abdominal versus peripheral obesity. Metabolism. 48, 1332-1335.

17. Corica F, Allegra A, Corsonello A, Buemi M, Calapai G, Ruello A, Nicita Mauro V, Ceruso D. (1999) Relationship between plasma leptin levels and the tumor necrosis factor-alpha system in obese subjects. Int J Obes Metab Disord. 23, 355-360.

18. Jovinge S, Hamsten A, Tornvall P, Proudler A, Bavenholm P, Ericsson CG, Godsland I, de Faire U, Nilsson J. (1998) Evidence for a role of tumor necrosis factor alpha in disturbances of triglyceride and glucose metabolism predisposing to coronary heart disease. Metabolism. 47, 113-118.

19. Koistinen HA, Bastard JP, Dusserre E, Ebeling P, Zegari N, Andreeli F, Jardel C, Donner M, Meyer L, Moulin P, Hainque B, Riou JP, Laville M, Koivisto VA, Vidal H. (2000) Subcutaneous adipose tissue expression of tumour necrosis factor-alpha is not associated with whole body insulin resistance in obese nondiabetic or in type-2 diabetic subjects. Eur J Clin Invest. 30, 302-310.

20. Zinman B, Hanley AJ, Harris SB, Kwan J, Fantus IG. (1999) Circulating tumor necrosis factor- $\alpha$ concentrations in a native canadian population with high rates of type 2 diabets mellitus. J Clin Endocrinol Metab 84. 272-278.

21. Bastard JP, Jardel C, Bruckert E, Blondy P, Capeau J, Laville M, Vidal H, Hinque B (2000) Elevated levels of interleukine 6 are reduced in serum and subcutaneous adipose tissue of obese women after weight loss. J Clin Endocrinol Metab. 85, 3338-3342.

22. Hube F, Hauner H. (1999) The role of TNF- $\alpha$ in human adipose tissue: prevention of weight gain at the expense of insulin resistance? Horm Metab Res. 31, 626-631.

23. Fawcett RL, Waechter AS, Williams LB, Zhang P, Louie R, Jones R, Inman M, Huse J, Considine RV. (2000) Tumor necrosis factor-alpha inhibits leptin production in subcutanous and omental adipocytes from morbidly obese humans. J Clin Endocrinol Metab. $85,530-535$.

24. Gonzalez F, Thusu K, Abdel-Rahman E, Prabhala A, Tomani M, Danhona P. (1999) Elevetaed serum levels of tumor necrosis factor alpha in normal-weight women with polycystic ovary syndrome. Metabolism. 48, 430-431.

25. Maltezos E, Papazoglou D, Exiara T, Papazoglou L, Karathanasis E, Christakidis D, Ktenidou-Kartali S. (2002) Tumour necrosis factor-alpha levels in non-diabetic offsprings of patients with type 2 diabetes mellitus. J Int Med Res. 30, 576-583.

26. Melczer Z, Banhidy F, Csomor S, Kovacs M, Siklos P, Winkler G, Cseh K. (2002) Role of tumour necrosis factor-alpha in insulin resistance during normal pregnancy. Eur J Obstet Gynecol Reprod Biol. 105, 7-10.

27. Bluher M, Kratzsch J, Paschke R. (2001) Plasma levels of tumor necrosis factor-alpha, angiotensin II, gowth hormone, and IGF-I are not elevated in insulin-resistant obese individuals with impaired glucose tolerance. Diabetes Care. 24, 328-334.

28. Demirbas B, Guler S, Cakir B, Culha C, Aral Y. (2002) Plasma tumor necrosis factor-alpha levels and inuslin resistance in nondiabetic hypertensive subjects. Horm Res. 58, 283-286.

29. Norberg M, Weinehall L, Lindahl B, Eriksson JW. (2002) Leptin, but not TNF alpha, interleukin-6 or CRP, is a prospective risk marker of type 2 diabetes independent of obesity. 38th Annual Meeting of the EASD. Budapest, Hungary 1-5 September, Abstracts, p. 117.

30. Goldstein BJ (2002) Insulin resistance as the core defect in type 2 diabetes mellitus. Am J Cardiol. 90, 3G-10G.

31. Robins SJ, Rubins HB, Faas FH, Schaefer EJ, Elam MB, Anderson JW, Collins D. (2003) Insulin resistance and cardiovascular events with low HDL cholesterol. Diabetes Care. 26, 1513-1517.

32. Hanley AJ, McKeown-Eyssen G, Harris SB, Hegele RA, Wolever TM, Kwan J, Zinman B. (2002) Cross-sectional and prospective assocations between abdominal adiposity and proinsulin concentration. J Clin Endocrinol Metab. 87, 77-83. 